\title{
Het effect van verificatie op volledigheid van klimaatgerelateerde informatie
}

\author{
Thijs Krukkert, Dick de Waard
}

Received 16 October $2019 \quad$ Accepted 28 May 2020 | Published 28 July 2020

\section{Samenvatting}

Verondersteld wordt dat de uitvoering van een assurance-opdracht een positief effect heeft op de volledigheid van onderzochte informatie. Zo blijkt uit meerdere onderzoeken. In het in deze bijdrage beschreven onderzoek is vastgesteld dat dit positieve effect bestaat ten aanzien van informatie over de uitstoot van broeikasgassen, indien een assurance-rapport is afgegeven bij het duurzaamheidsverslag van ondernemingen in de nutsector, waarin deze klimaatgerelateerde informatie is opgenomen. Daarbij is vastgesteld dat de invoering van de EU NFI Directive dit effect zeer beperkt heeft versterkt. Omdat in dit onderzoek het overgrote deel van de assurance-opdrachten is uitgevoerd door accountants, kan niet worden vastgesteld of sprake is van een verschil in invloed door de uitvoering van de assurance-opdracht door accountants of niet-accountants.

\section{Relevantie voor de praktijk}

Assurance bij niet-financiële informatie leidt tot de vaststelling of de gepresenteerde informatie al dan niet betrouwbaar is. Een belangrijk aspect van de betrouwbaarheid van informatie betreft de volledigheid daarvan. Het feit dat assurance bij niet-financiële informatie de volledigheid van informatie over de uitstoot van broeikasgassen ten goede komt, geeft aan dat assurance relevant is en dat een flink aantal ondernemingen - waarbij (nog) geen sprake is van een assurance-rapport bij het duurzaamheidsverslag - nog een forse verbeteringsslag kan realiseren als het gaat om de volledigheid van informatie over met name de feitelijke uitstoot van broeikasgassen.

\section{Trefwoorden}

Assurance-opdracht, niet-financiële informatie, broeikasgassen, transparantie, volledigheid

\section{Inleiding}

Klimaatverandering is een zeer actueel thema. Zeker sinds het akkoord van Parijs in 2015 is zichtbaar dat de discussie over klimaatverandering en de invloed daarop door het menselijk handelen in toenemende mate het nieuws beheerst. De Nederlandse overheid heeft medio 2019 haar Klimaatakkoord openbaar gemaakt. Daarin zijn maatregelen opgenomen die moeten leiden tot een substantiële reductie van de uitstoot van broeikasgassen. Dit is een proces dat zich niet alleen in Nederland voltrekt. Ook de overheden van andere landen binnen en buiten de EU ontwikkelen plannen en ondernemen acties gericht op een zogenaamde low carbon economy.
Bij de Rijksuniversiteit Groningen wordt door studenten in de bachelor- en master-opleiding reeds een aantal jaren onderzoek gedaan naar de transparantie door ondernemingen over hun uitstoot van broeikasgassen. In het navolgende wordt een toelichting gegeven bij het doel van het onderzoek, de theoretische inbedding, de hypothesen, de onderzoeksmethode en de uitkomsten. In de laatste paragraaf zijn de conclusie en aanbevelingen opgenomen.

\section{Doel van het onderzoek}

Ondernemingen moeten gericht zijn op langetermijnwaardecreatie. Dat kan worden afgeleid uit de Nederland- 
se Corporate Governance Code. Uit onderzoek (Schoolderman et al. 2017) komt naar voren, dat gebruikers van jaarverslaggeving ook daadwerkelijk vragen om inzicht in de langetermijnwaardecreatie van ondernemingen. Deze vraag om transparantie bestaat niet alleen in Nederland, maar heeft binnen de EU mede ertoe geleid, dat in 2017 de EU Richtlijn 2014/95/EU van kracht is geworden. Deze richtlijn beschrijft in algemene termen de gevraagde transparantie over relevante duurzaamheidsvraagstukken en biedt daarmee veel ruimte aan ondernemingen om de verslaggeving daarover naar eigen inzicht in te vullen. Andere - reeds langer bestaande - richtlijnen zoals de GRI (Global Reporting Initiative) ontberen een wettelijke basis en geven daarmee een vergelijkbare speelruimte aan ondernemingen. De richtlijn 2014/95/EU betreft het bestuursverslag van de onderneming en de GRI-richtlijnen worden over het algemeen ingezet bij duurzaamheidsverslaggeving. Dit zijn - uitgezonderd situaties waar sprake is van een vergaande integratie van verslaggeving - verschillende jaarverslagen. In dit onderzoek is de aandacht primair uitgegaan naar duurzaamheidsverslaggeving.

Het hiervoor gememoreerde vrijwillige karakter van duurzaamheidsverslaggeving legitimeert de vraag naar assurance bij niet-financiële informatie en de vraag naar assurance neemt in de praktijk ook toe (Deegan et al. 2002; Lee and Hutchinson 2005; Alciatore and Callaway 2006). De perceptie van en het vertrouwen in de geloofwaardigheid en betrouwbaarheid van duurzaamheidsverslagen kan verbeteren door de uitvoering van assurance-opdrachten (Zadek et al. 2004; Park and Brorson 2005; Adams and Frost 2008; Hodge et al. 2009; Simnett et al. 2009; Fonseca 2010; Pflugrath et al. 2011; Gillet 2012; Casey and Grenier 2014; Rossi and Tarquinio 2017). Ondanks deze toeneming in de vraag naar assurance, staat de uitvoering van assurance-opdrachten nog min of meer in de kinderschoenen, zeker in vergelijking met assurance-opdrachten bij financiële informatie (O'Dwyer and Owen 2007; Hummel et al. 2017; Farooq and De Villiers 2019).

Mede doordat verslaggeving inzake niet-financiële informatie nog grotendeels plaatsvindt op basis van vrijwilligheid en ook assurance bij deze informatie niet is voorgeschreven, worden assurance-opdrachten niet alleen door accountants uitgevoerd, maar ook door andere professionele dienstverleners. Omdat er ook geen algemeen bindende voorschriften bestaan, is sprake van verschillen in uitvoering, zekerheidsniveau en rapportering over de uitkomsten van dit soort assurance-opdrachten.

$\mathrm{Bij}$ accountants is inmiddels sprake van een zeker niveau van standaardisering. Assurance-rapporten van accountants onderscheiden zich daarmee van de assuran$c e$-rapporten van andere professionele dienstverleners. Accountants zijn - mede ingegeven door de restrictieve werking van de door hen gehanteerde (voorgeschreven) controlestandaarden - voorzichtiger in de uitvoering van hun werk en zijn meer gericht op de kwantificering van de niet-financiële informatie, waardoor de uitkomsten van hun werk een hogere mate van zekerheid geven (O’Dwyer and Owen 2005; Dillard 2011; O’Dwyer 2011).
Een zeer actueel aspect van niet-financiële informatie betreft de informatie over de uitstoot van broeikasgassen. Klimaatverandering beheerst het nieuws en overheden conformeren zich aan de internationale wens om maatregelen te treffen die de uitstoot van broeikasgassen terugdringen. Onderzoekers stellen dat het vaststellen van met name de volledigheid van de informatie in duurzaamheidsverslagen - waaronder de uitstoot van broeikasgassen - een moeilijk realiseerbare opdracht is (Adams 2004; Martinov-Bennie et al. 2012). Dit vraagstuk en de ontwikkelingen op het gebied van assurance bij niet-financiële informatie geven richting aan de vraag of ondernemingen transparant zijn over hun uitstoot van broeikasgassen en of sprake is van beïnvloeding daarvan door de invoering van de EU Richtlijn en het verstrekken van assurance bij deze informatie. De centrale vraag in dit onderzoek is daarmee als volgt:

Wordt de volledigheid van informatie over uitstoot van broeikasgassen in duurzaamheidsverslagen positief beïnvloed door externe assurance bij het duurzaamheidsverslag en wordt deze relatie beïnvloed door het type assurance provider en door de invoering van de EU Richtlijn?

\section{Theoretische inbedding}

De theoretische basis voor het onderzoek wordt gevonden in het raakvlak tussen de legitimiteits-, stakeholder- en agency-theorie. Waar de legitimiteitstheorie de maatschappelijke rol van de ondernemingen beschouwt, heeft de stakeholder-theorie een focus op specifieke groepen van belanghebbenden uit de maatschappelijke omgeving. De agency-theorie beschrijft het vraagstuk van mogelijk tegengestelde belangen tussen de leiding van de onderneming (de agent) en de belanghebbenden - waaronder de eigenaren - en de maatschappij (de principalen) en het vraagstuk van de informatieasymmetrie. De maatschappij en specifieke belanghebbenden hebben te allen tijde een grote informatieachterstand ten opzichte van de ondernemingsleiding (Jensen and Meckling 1976; Eisenhardt 1989).

In de legitimiteitstheorie wordt er vanuit gegaan dat de onderneming een sociaal contract heeft met de maatschappij en dat de onderneming naar dit contract moet handelen om haar voortbestaan te borgen. Dit houdt in concreto in, dat de onderneming zich conformeert aan maatschappelijke normen en verwachtingen (Suchman 1995; Palazzo and Scherer 2006). De publicatie van duurzaamheidsverslagen en de verificatie daarvan helpen ondernemingen met de communicatie hieromtrent aan de maatschappij (Park and Brorson 2005; Kuruppu and Milne 2010; Smith et al. 2011; Perego and Kolk 2012; Cohen and Simnett 2015; De Beelde and Tuybens 2015; Bepari and Mollik 2016).

De stakeholder theorie (Freeman 1999) is relevant voor ondernemingen, omdat - analoog aan de legitimiteit van de onderneming - de focus op de wensen en eisen van de relevante stakeholders in combinatie met duurzaamheidsverslaggeving van belang is voor het voortbestaan van de onderneming (Ullmann 1985; Roberts 1992; Freeman 2010). 


\section{Verwachtingen en hypothesen}

Uit onderzoeken is naar voren gekomen dat ten aanzien van duurzaamheidsinformatie - waaronder ook de informatie omtrent de uitstoot van broeikasgassen - de volledigheid van de informatie de belangrijkste, maar ook meest uitdagende kwaliteitsvereiste en verificatiedoelstelling is (Adams and Evans 2004; Martinov-Bennie et al. 2012; Helfaya et al. 2019). Adams and Evans (2004) signaleren dat in duurzaamheidsverslagen sprake is van onvolledigheid en dat onvolledigheid in dezelfde mate niet voorkomt in financiële verslaggeving. De oorzaak daarvan kan liggen in de kwaliteit van de norm (stringente jaarverslaggevingsvoorschriften), maar ook in de inzet van een externe onafhankelijke partij die de kwaliteit van deze informatie toetst. Mede op basis hiervan en van het eerder gememoreerde belang van assurance bij duurzaamheidsverslaggeving, luidt de eerste hypothese:

H1: Een assurance-opdracht bij duurzaamheidsverslaggeving heeft een positieve invloed op de volledigheid van informatie over de uitstoot van broeikasgassen in het duurzaamheidsverslag.

Door het ontbreken van een wettelijke basis en een gestandaardiseerde aanpak, wordt de verificatie van duurzaamheidsinformatie door zowel accountants als niet-accountants op verschillende manieren uitgevoerd (Martinov-Bennie et al. 2012). Accountants opereren daarbij voorzichtiger en streven een hoger niveau van zekerheid na (O’Dwyer and Owen 2005; O’Dwyer 2011). Waar accountants meer gefocust zijn op de kwaliteit van de informatie, zijn niet-accountants meer gericht op de duurzaamheidsvraagstukken zelf (Dillard 2011). De kwaliteit van de verificatie is daarmee afhankelijk van de professional die de verificatiewerkzaamheden uitvoert (Hummel et al. 2017).

H2: Het positieve effect van assurance op de volledigheid van informatie over de uitstoot van broeikasgassen wordt gemitigeerd indien de verificatie is uitgevoerd door niet-accountants.

De toenemende vraag naar transparantie omtrent duurzaamheid heeft geleid tot de invoering van de EU Richtlijn voor een aangewezen groep ondernemingen (grote ${ }^{1}$ organisaties van openbaar belang). Deze richtlijn betreft diverse aspecten van niet-financiële informatie die moet worden opgenomen in het bestuursverslag van de onderneming. De handvatten die door de EU zijn gegeven ten aanzien van het bestuursverslag kunnen worden gezien als een aanvullende norm, waarmee wordt verwacht dat daarvan een versterkende werking uitgaat op het effect van de assurance-opdracht. Om die reden leidt de invoering van de EU richtlijn tot de derde hypothese.

H3: De invoering van de EU Richtlijn heeft een versterkend effect op het positieve effect van assurance op de volledigheid van informatie over de uitstoot van broeikasgassen.

\section{De onderzoeksmethode}

Het onderzoek richt zich op de verslaggeving door ondernemingen in de Europese Unie. De verslaggeving die in het onderzoek wordt betrokken, betreft de duurzaamheidsverslagen en de duurzaamheidssecties uit geïntegreerde jaarverslagen over de jaren 2015, 2016 en 2017. Gekozen is voor deze jaren, omdat daardoor het mogelijke effect van de invoering van de EU Richtlijn in 2017 kan worden vastgesteld. Het onderzoek richt zich daarbij specifiek op de informatie die door de geselecteerde ondernemingen wordt verstrekt over (het terugdringen van) de emissies van broeikasgassen.

Het onderzoek richt zich specifiek op ondernemingen in de nutsector, omdat deze ondernemingen veelal een omvangrijke hoeveelheid broeikasgassen uitstoten en daardoor bloot staan aan de publieke aandacht en zorg omtrent klimaatverandering (Simnett et al. 2009). Deze sector bestaat uit ondernemingen die zich bezighouden met de levering van elektriciteit, gas en water. De selectie bestaat uit 61 ondernemingen die over de jaren 2015, 2016 en/of 2017 in totaliteit 137 duurzaamheids- en/of geïntegreerde jaarverslagen hebben gepubliceerd.

Om vast te stellen in welke mate ondernemingen transparant zijn over hun impact op het klimaat door de uitstoot van broeikasgassen, is gebruik gemaakt van de benchmark die is ontwikkeld door Chithambo and Tauringana (2017), die bestaat uit 60 criteria. Daaraan zijn negen criteria toegevoegd (a tot en met i), die enkele aanvullende criteria betreffen, gericht op een nadere detaillering van emissiedata en de uitvoering van de eventuele assurance-opdracht. Met de toepassing van deze benchmark is invulling gegeven aan de concretisering van bestaande richtlijnen voor duurzaamheidsverslaggeving, vanwege het gedetailleerde en diepgaande karakter daarvan. Daarmee is voor dit onderzoek volledigheid gedefinieerd als de mate waarin een onderneming in haar klimaatgerelateerde verslaggeving voldoet aan deze benchmark.

De afhankelijke variabele in het onderzoek betreft de transparantiescore. Om deze score te bepalen wordt gebruik gemaakt van de benchmark (zie Bijlage 1), waarbij de criteria 52, e en f worden uitgesloten, omdat deze nadere informatie geven over de eventueel uitgevoerde $a s$ surance-opdracht. De maximale score uit de benchmark (op basis van scores 1 of 0 ) is 66 punten.

De onafhankelijke variabele betreft de aan- of afwezigheid van een assurance-opdracht. Waarbij de assurance-opdracht kan worden uitgevoerd door een niet-accountant (NASAP) of een accountant (ASAP). De keuze tussen NASAP of ASAP (criterium e) wordt ingezet als modererende variabele, waarbij NASAP een dummy variabele betreft. De tweede modererende variabele betreft de vraag of de EU Richtlijn van toepassing is of niet (1 of 0 ). Deze variabele wordt beïnvloed door het jaartal (invoering in 2017) en doordat de EU Richtlijn niet voor iedere onderneming van toepassing is. In het onderzoek is gekozen voor een analyse op de jaren 2015, 2106 en 2017, omdat ondernemingen mogelijk al in 2016 in hun 
Tabel 1. Overzicht variabelen.

\begin{tabular}{|c|c|c|}
\hline Afhankelijke variabele & $G H G S C_{i}=$ broeikasgas transparantiescore & $\begin{array}{l}\text { Uitkomst van de uitvoering van de benchmark (exclusief } \\
\text { criteria } 52 \text {, e en f). }\end{array}$ \\
\hline Onafhankelijke variabele & $\begin{array}{l}3^{\text {rd }} P A=\text { Assurance-opdracht door een externe partij } \\
\text { verricht }\end{array}$ & Uitkomst van criterium 52: 1 of 0 \\
\hline \multirow[t]{2}{*}{ Modererende variabele } & $\begin{array}{l}N_{A S A P_{i}}=\text { Assurance-opdracht verricht door niet- } \\
\text { accountant. Dummy variabele. }\end{array}$ & Uitkomst van criterium e: 1 of 0 . \\
\hline & $E U$ Dir $_{i}=$ EU Richtlijn van toepassing & Van toepassing $=1 ;$ Niet van toepassing $=0$ \\
\hline \multirow[t]{2}{*}{ Controle variabele } & 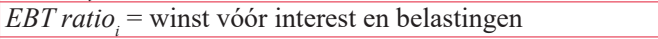 & Monetaire waarde \\
\hline & $\begin{array}{l}\text { LOG TotalAssets } \\
\text { in totale activa }\end{array}$ & Nlog van monetaire waarde \\
\hline
\end{tabular}

verslaggeving zijn vooruitgelopen op de invoering van de EU Richtlijn in 2017.

Onderzoeken naar de invloed van de rendementen van ondernemingen op klimaatgerelateerde informatieverstrekking geven een wisselend beeld. Volgens een aantal onderzoekers is sprake van een positieve relatie (Liu and Anbumozhi 2009; Berthelot and Robert 2011). Andere onderzoekers hebben geen duidelijke relatie kunnen vaststellen (Prado-Lorenzo et al. 2009; Rankin et al. 2011; Peters and Romi 2012). In dit onderzoek is er voor gekozen het rendement als controlevariabele in te zetten vanwege de door de eerst genoemden aangetoonde correlatie. De omvang van de onderneming heeft volgens meerdere onderzoekers wel een duidelijke positieve relatie met de klimaatgerelateerde transparantie (Freedman and Jaggi 2005; Brammer and Pavelin 2008; Stanny and Ely 2008; Prado-Lorenzo et al. 2009; Berthelot and Robert 2011; Rankin et al. 2011; Peters and Romi 2012). Hoe groter de onderneming, hoe groter de impact en publieke aandacht. Ondernemingen reageren daar onder meer op door meer informatie over de impact op het klimaat te geven (Henriques and Sadorsky 1999). Het rendement van de onderneming (winst voor belastingen) en de omvang van de onderneming (totaal activa) zijn als controlevariabele in het onderzoek betrokken.

\section{De uitkomsten}

\subsection{Beschrijvende statistiek}

In het onderzoek zijn 61 ondernemingen betrokken uit 20 EU-landen. Door deze ondernemingen zijn over de jaren 2015 - 2017137 duurzaamheidsverslagen of geïntegreerde verslagen gepubliceerd. Van deze 61 ondernemingen is voor 41 ondernemingen de EU Richtlijn van toepassing
Tabel 2. EU-Richtlijn en aard van de activiteiten.

\begin{tabular}{lcccc} 
& EU Richtlijn van toepassing & \multicolumn{2}{c}{ Activiteiten } \\
& Ja & Nee & Water & Energie \\
Aantal & 41 & 20 & 10 & 51 \\
Percentage & 67,2 & 32,8 & 16,4 & 83,6 \\
\hline
\end{tabular}

en zijn er 51 actief op het gebied van energieproductie en 10 op het gebied van watervoorziening, zie Tabel 2 .

In Tabel 3 is inzichtelijk gemaakt hoeveel van de in het onderzoek betrokken jaarverslagen zijn voorzien van assurance en bij welk aantal daarvan de assurance-opdracht is uitgevoerd door een accountant of een niet-accountant. Hieruit blijkt, dat bij de geselecteerde groep ondernemingen de assurance-opdracht hoofdzakelijk door accountants is uitgevoerd. In één geval was het niet mogelijk om vast te stellen of sprake was van een accountant of niet-accountant.

Een trendanalyse op de uitkomsten laat zien dat sprake is van een oplopende gemiddelde en minimumscore op basis van de benchmark. De standaardafwijking neemt af. Dit doet vermoeden dat sprake is van toenemende transparantie over de gehele linie op het gebied van klimaatgerelateerde informatie. Opvallend is, dat de gemiddelde score in 2016 hoger is dan in 2017. Daarbij is naar verwachting sprake van een invloed door het kleiner aantal verslagen over 2017 dat in het onderzoek is betrokken. Tijdens het onderzoek is namelijk vastgesteld, dat een aantal verslagen in een zeer laat stadium is gepubliceerd (één van de verslagen over 2017 heeft als publicatiedatum 8 mei 2019).

Een interessante bevinding die uit de analyses naar voren is gekomen, is dat de hoogste transparantiescores zijn gemeten in de verslagen die het laatst zijn gepubliceerd. Een belangrijke constatering is ook, dat ieder jaar de gemiddelde en de hoogste score beduidend lager zijn dan de maximale score (66 punten). Uit het onderzoek wordt

Tabel 3. Assurance-opdrachten en assurance-verlener.

\begin{tabular}{|c|c|c|c|c|c|c|c|c|}
\hline \multirow{2}{*}{$\begin{array}{c}\text { Assurance } \\
\text { Opdracht }\end{array}$} & \multicolumn{2}{|c|}{2017} & \multicolumn{2}{|c|}{2016} & \multicolumn{2}{|c|}{2015} & \multicolumn{2}{|c|}{ Totaal } \\
\hline & Aantal & $\%$ & Aantal & $\%$ & Aantal & $\%$ & Aantal & $\%$ \\
\hline Nee & 18 & 47,4 & 23 & 42,6 & 21 & 46,7 & 62 & 45,3 \\
\hline $\mathrm{Ja}$ & 20 & 52,6 & 31 & 57,4 & 24 & 53,3 & 75 & 54,7 \\
\hline Verlener & & & & & & & & \\
\hline ASAP & 18 & 90,0 & 26 & 83,9 & 19 & 79,2 & 63 & 84,0 \\
\hline NASAP & 2 & 10,0 & 5 & 16,1 & 4 & 16,7 & 11 & 14,7 \\
\hline n.v.t. & 0 & 0,0 & 0 & 0,0 & 1 & 4,1 & 1 & 1,3 \\
\hline
\end{tabular}


Tabel 4. Trendanalyse uitkomsten benchmark.

\begin{tabular}{lccccc} 
& N & Mean & $\begin{array}{c}\text { Standard } \\
\text { deviation }\end{array}$ & Minimum & Maximum \\
\hline Score 2017 & 38 & 21,42 & 9,753 & 4 & 39 \\
Score 2016 & 54 & 21,65 & 10,806 & 3 & 43 \\
Score 2015 & 45 & 18,11 & 10,287 & 1 & 37 \\
\hline
\end{tabular}

duidelijk dat met name helder geanalyseerde informatie omtrent de feitelijke uitstoot van broeikasgassen en de toekomstverwachtingen lager scoren en dus nog onvoldoende in de onderzochte verslagen aan de orde komen.

\subsection{Correlatie}

In de correlatietabel 2017 (Tabel 5a) is zichtbaar dat sprake is van een significant positieve relatie van externe assurance $\left(3^{\text {rd }} \mathrm{PA}\right)$ op de volledigheid van de klimaatgerelateerde informatie in de duurzaamheidsverslagen en geïntegreerde verslagen van de geselecteerde ondernemingen $(\mathrm{p}<0,01)$. Daarnaast is sprake van een gematigde positieve invloed door de invoering van de EU Richtlijn $(\mathrm{p}<0,10)$.

De analyse over 2016 (Tabel 5b) laat zien dat sprake is van een zeer significante relatie $(p<0,01)$ tussen de uitvoering van een externe assurance-opdracht en de volledigheid van de klimaatgerelateerde informatie in de duurzaamheidsverslagen en geïntegreerde verslagen.

Ook in de uitkomsten over 2015 (Tabel 5c) blijkt dat sprake is van een significante positieve relatie $(p<0,01)$ tussen de uitvoering van een externe assurance-opdracht en de volledigheid van de klimaatgerelateerde informatie in de duurzaamheidsverslagen en geïntegreerde verslagen. Een vergelijkbare significante relatie $(p<0,01)$ is zichtbaar tussen het totaal van de activa (LOG TotAssets) en de klimaatgerelateerde transparantie.

Overigens blijkt uit de uitkomsten van alle drie de jaren dat geen sprake is van multicollineariteit.

\subsection{Regressieanalyse}

In Tabel 6 is zichtbaar dat in alle drie de jaren sprake is van een sterk significante positieve relatie tussen de uitvoering van een externe assurance-opdracht en de volledigheid van de klimaatgerelateerde informatie in de duurzaamheidsverslagen en geïntegreerde verslagen $(p<0,01)$. Dit houdt in, dat hypothese 1 kan worden aangenomen. De inzet van de controlevariabelen EBT ratio en LOG TotAssets leert dat deze variabelen de uitkomst niet beïnvloeden.

De invloed van de invoering van de EU Richtlijn op de relatie tussen de uitvoering van een assurance-opdracht en de volledigheid van de klimaatgerelateerde informatie wordt per jaar geanalyseerd in Tabel 7a tot en met 7c, waarin model 1 de invloed van de controlevariabelen betreft, model 2 de invloed van sec de assurance-opdracht en de EU richtlijn en model 3 de combinatie van de assurance-opdracht en de EU richtlijn. Uit deze analyses blijkt, dat sprake is van een beperkte invloed van de invoering

Tabel 5a. Correlatie 2017.

\begin{tabular}{|c|c|c|c|c|c|c|c|c|}
\hline & Mean & Std Dev & (1) & (2) & (3) & (4) & (5) & (6) \\
\hline (1) GHG SC 2017 & 21.42 & 9.753 & - & & & & & \\
\hline (2) $3^{\text {rd }} \mathrm{PA}$ & 0.53 & 0.506 & $0.595 * * *$ & - & & & & \\
\hline (3) EU Dir & 0.67 & 0.473 & $0.306^{*}$ & 0.151 & - & & & \\
\hline (4) NASAP & 0.0526 & 0.22629 & 0.186 & 0.224 & $-0.394 * *$ & - & & \\
\hline (5) EBT ratio & 0.0365141696 & 0.0437836995 & $0.272 *$ & $0.419 * * *$ & 0.164 & 0.139 & - & \\
\hline (6) LOG TotAssets & 9.879019640 & 0.6470761878 & $0.589 * * *$ & $0.322 * *$ & 0.158 & -0.052 & $0.286^{*}$ & - \\
\hline
\end{tabular}

$* \mathrm{p}<0.10, * * \mathrm{p}<0.05, * * * \mathrm{p}<0.01$

Tabel 5b. Correlatie 2016.

\begin{tabular}{|c|c|c|c|c|c|c|c|c|}
\hline & Mean & Std Dev & (1) & (2) & (3) & (4) & (5) & (6) \\
\hline (1) GHG SC 2016 & 21.65 & 10.806 & - & & & & & \\
\hline (2) $3^{\text {rd } P A}$ & 0.57 & 0.499 & $0.657 * * *$ & - & & & & \\
\hline (3) EU Dir & 0.67 & 0.473 & 0.209 & 0.061 & - & & & \\
\hline (4) NASAP & 0.0926 & 0.29258 & 0.034 & $0.275 * *$ & $-0.334 * *$ & - & & \\
\hline (5) EBT ratio & 0.0335071924 & 0.0432287365 & 0.033 & 0.195 & $0.302 * *$ & 0.005 & - & \\
\hline (6) LOG TotAssets & 9.887261625 & 0.6553479152 & $0.621 * * *$ & 0.213 & 0.149 & -0.164 & 0.020 & - \\
\hline
\end{tabular}

$* p<0.10, * * p<0.05, * * * p<0.01$

Tabel 5c. Correlatie 2015

\begin{tabular}{|c|c|c|c|c|c|c|c|c|}
\hline & Mean & Std Dev & (1) & (2) & (3) & (4) & (5) & (6) \\
\hline (1) GHG SC 2015 & 18.11 & 10.287 & - & & & & & \\
\hline (2) $3^{\text {rd } P A}$ & 0.53 & 0.505 & $0.540 * * *$ & - & & & & \\
\hline (3) EU Dir & 0.67 & 0.473 & 0.171 & -0.007 & - & & & \\
\hline (4) NASAP & 0.0889 & 0.28780 & -0.080 & $0.292 *$ & -0.145 & - & & \\
\hline (5) EBT ratio & 0.0246679526 & 0.0671412440 & -0.014 & 0.214 & 0.108 & 0.129 & - & \\
\hline (6) LOG TotAssets & 9.969898919 & 0.6402549224 & $0.572 * * *$ & 0.216 & 0.055 & $-0.279 *$ & 0.018 & - \\
\hline
\end{tabular}

$* p<0.10, * * p<0.05, * * * p<0.01$ 
Tabel 6. Onafhankelijke variabele regressie.

\begin{tabular}{lccc} 
& GHG SC 2017 & GHG SC 2016 & GHG SC 2015 \\
$3^{\text {rdPA }}$ & $9.100 * * *(2.559)$ & $12.293 * * *(1.803)$ & $9.454 * * *(2.306)$ \\
EBT ratio & $-12.356(29.226)$ & $-21.942(20.345)$ & $-18.698(16.919)$ \\
Log TotAssets & $6.828 * * *(1.896)$ & $8.268 * * *(1.347)$ & $7.617 * * *(1.775)$ \\
Constant & $-50.367(18.312)$ & $-66.425 * * *(13.187)$ & $-62.408 * * *(17.517)$ \\
Observations & 38 & 54 & 45 \\
$\mathrm{R}^{2}$ & 0.533 & 0.682 & 0.523 \\
Adjusted $\mathrm{R}^{2}$ & 0.491 & 0.662 & 0.489 \\
\hline$p<0.10, * * p<0.05, * * * p<0.01$ & &
\end{tabular}

Tabel 7a. Modererende variabele EU-Richtlijn regressie 2017.

\begin{tabular}{|c|c|c|c|c|c|c|}
\hline \multirow[t]{2}{*}{ Steps \& variables } & \multicolumn{2}{|c|}{ Model 1} & \multicolumn{2}{|c|}{ Model 2} & \multicolumn{2}{|c|}{ Model 3} \\
\hline & B & SE & B & SE & B & SE \\
\hline Constant & - & $(20.775)$ & - & $(18.338)$ & - & $(19.256)$ \\
\hline & $62.403 * * *$ & & $42.888 * *$ & & $47.934 * *$ & \\
\hline \multicolumn{7}{|l|}{ Control } \\
\hline EBT ratio & 25.135 & $(31.466)$ & -16.458 & $(28.793)$ & -16.631 & $(28.887)$ \\
\hline LOG TotAssets & $8.392 * * *$ & $(2.129)$ & $6.545 * * *$ & $(1.869)$ & $7.075 * * *$ & (1.968) \\
\hline \multicolumn{7}{|l|}{ Main effects } \\
\hline $3^{\text {rd }} \mathrm{PA}$ & & & $4.473 * * *$ & $(1.273)$ & $4.538 * * *$ & $(1.279)$ \\
\hline EU dir & & & 1.861 & $(1.217)$ & 1.636 & (1.247) \\
\hline \multicolumn{7}{|l|}{ Two-way interaction } \\
\hline $3^{\text {rd }} \mathrm{PA} \times \mathrm{EU}$ dir & & & & & -1.146 & $(1.292)$ \\
\hline $\mathrm{R}^{2}$ & 0.359 & & 0.563 & & 0.574 & \\
\hline Adjusted $\mathrm{R}^{2}$ & $0.322 * * *$ & & $0.511 * * *$ & & 0.507 & \\
\hline
\end{tabular}

$* \mathrm{p}<0.10, * * \mathrm{p}<0.05, * * * \mathrm{p}<0.01$

Tabel 7b. Modererende variabele EU-Richtlijn regressie 2016.

\begin{tabular}{|c|c|c|c|c|c|c|}
\hline \multirow[t]{2}{*}{ Steps \& variables } & \multicolumn{2}{|c|}{ Model 1} & \multicolumn{2}{|c|}{ Model 2} & \multicolumn{2}{|c|}{ Model 3} \\
\hline & B & SE & B & SE & B & SE \\
\hline \multirow[t]{2}{*}{ Constant } & - & (17.943) & - & (13.318) & - & (13.369) \\
\hline & $79.620 * * *$ & & $55.594 * * *$ & & $55.585^{* * *}$ & \\
\hline \multicolumn{7}{|l|}{ Control } \\
\hline EBT ratio & 5.183 & $(27.444)$ & -32.729 & $(20.953)$ & -29.517 & $(21.417)$ \\
\hline LOG TotAssets & $10.225 * * *$ & $(1.810)$ & $7.919 * * *$ & $(1.338)$ & $7.912 * * *$ & (1.343) \\
\hline \multicolumn{7}{|l|}{ Main effects } \\
\hline $3^{\text {rd }} \mathrm{PA}$ & & & $6.182 * * *$ & $(0.884)$ & $6.167 * * *$ & $(0.887)$ \\
\hline EU dir & & & $1.543^{*}$ & $(0.907)$ & 1.470 & $(0.915)$ \\
\hline \multicolumn{7}{|l|}{ Two-way interaction } \\
\hline $3^{\text {rd }} \mathrm{PA} \times \mathrm{EU}$ dir & & & & & -0.698 & $(0.878)$ \\
\hline $\mathrm{R}^{2}$ & 0.385 & & 0.699 & & 0.703 & \\
\hline Adjusted $\mathrm{R}^{2}$ & $0.361 * * *$ & & $0.675 * * *$ & & 0.672 & \\
\hline
\end{tabular}

$* p<0.10, * * p<0.05, * * * p<0.01$

Tabel 7c. Modererende variabele EU Richtlijn regressie 2015.

\begin{tabular}{|c|c|c|c|c|c|c|}
\hline \multirow[t]{2}{*}{ Steps \& variables } & \multicolumn{2}{|c|}{ Model 1} & \multicolumn{2}{|c|}{ Model 2} & \multicolumn{2}{|c|}{ Model 3} \\
\hline & B & SE & $\mathbf{B}$ & SE & B & SE \\
\hline Constant & - & $(20.305)$ & - & $(17.495)$ & - & (17.788) \\
\hline & $73.518 * * *$ & & $55.802 * *$ & & $55.668 * *$ & \\
\hline \multicolumn{7}{|l|}{ Control } \\
\hline EBT ratio & -3.771 & $(19.385)$ & -21.614 & $(16.757)$ & -21.766 & $(17.064)$ \\
\hline LOG TotAssets & $9.200 * * *$ & $(2.033)$ & $7.453 * * *$ & $(1.750)$ & $7.440 * * *$ & $(1.779)$ \\
\hline \multicolumn{7}{|l|}{ Main effects } \\
\hline $3^{\text {rdPA }}$ & & & $4.845 * * *$ & $(1.146)$ & $4.841 * * *$ & $(1.161)$ \\
\hline EU dir & & & 1.740 & $(1.136)$ & 1.741 & (1.151) \\
\hline \multicolumn{7}{|l|}{ Two-way interaction } \\
\hline $3^{\text {rd }} \mathrm{PA} \times \mathrm{EU}$ dir & & & & & 0.098 & $(1.165)$ \\
\hline $\mathrm{R}^{2}$ & 0.328 & & 0.550 & & 0.550 & \\
\hline Adjusted $\mathrm{R}^{2}$ & $0.296^{* * *}$ & & $0.505^{* * *}$ & & 0.492 & \\
\hline
\end{tabular}


van de EU Richtlijn. In 2016 (Tabel 7b) valt op dat sprake is van een significante directe relatie $(p<0,10)$ tussen de invoering van de EU Richtlijn en de volledigheid van de klimaatgerelateerde informatie in de jaarverslagen. Dit zou kunnen betekenen dat het bekend worden van de invoering van de richtlijn enig effect scoorde. De score is echter over alle drie de jaren niet zodanig dat sprake is van een duidelijke invloed van de invoering van de EU Richtlijn. Om die reden wordt hypothese 3 verworpen.

Uit het onderzoek blijkt dat sprake was van een zeer beperkt aantal jaarverslagen waarbij een assurance-rapport was afgegeven door niet-accountants. In de correlatietabel (Tabel 5a tot en met 5c) blijkt dat sprake is van enkele significante relaties tussen NASAP en het voorkomen van assurance-rapporten in de jaarverslagen ( $\left.3^{\text {rd }} \mathrm{PA}\right)$. Deze relatie zal door nader onderzoek moeten worden geanalyseerd. Daarvoor zal een grotere deelwaarneming noodzakelijk zijn. Hypothese 2 wordt derhalve niet aangenomen.

\section{Conclusies en aanbevelingen}

Onderzocht is of sprake is van invloed van assurance-opdrachten bij duurzaamheidsverslaggeving door ondernemingen in de nutsector op de volledigheid van de daarin opgenomen informatie over de uitstoot van broeikasgassen. Daarnaast is onderzocht of de invoering van de EU NFI Directive en het onderscheid tussen een assurance-opdracht uitgevoerd door accountants en niet-accountants van invloed zijn op bovenstaande relatie.

De resultaten van deze studie wijzen uit dat de primair onderzochte relatie significant aanwezig is (tweezijdig; $\mathrm{p}<$ 0.01) in alle onderzochte jaren (2015-2017). Dit houdt in dat de volledigheid van de klimaatgerelateerde informatie in het duurzaamheidsverslag toeneemt, indien sprake is van een assurance-opdracht bij het duurzaamheidsverslag. De resultaten omtrent de invloed van de invoering van de EU NFI Directive zijn niet significant. De oorzaak daarvoor kan worden gezocht in het feit, dat ondernemingen reeds voor de invoering van deze richtlijn de impact op het klimaat hadden omarmd als relevant thema. Ten slotte is de invloed van assurance-opdrachten uitgevoerd door niet-accountants door het beperkte aantal waarnemingen niet meetbaar gebleken.

Toekomstig onderzoek op dit gebied kan worden uitgevoerd in meer sectoren en in landen waar de EU NFI Directive niet van toepassing is. Daarnaast kan de invloed van assurance-opdrachten door niet-accountants worden onderzocht door gebruik te maken van een grotere onderzoekspopulatie.

In het in deze bijdrage beschreven onderzoek is gebruik gemaakt van een uitgebreide benchmark gericht op klimaatgerelateerde informatie. Uitgaande van de conclusie van Helfaya et al. (2019) dat de volledigheid van informatie één van de belangrijkste maatstaven is voor de kwaliteit van een duurzaamheidsverslag, kan worden geconcludeerd dat assurance bij een duurzaamheidsverslag een positieve invloed heeft op de kwaliteit van de daarin opgenomen informatie. Opgemerkt dient te worden, dat in het onderzoek niet is duidelijk gemaakt of deze positieve invloed op de kwaliteit van de klimaatgerelateerde informatie wordt veroorzaakt doordat de onderneming die een accountant inschakelt intrinsiek gemotiveerd transparant rapporteert, of dat dit wordt veroorzaakt door de inbreng van de accountant.

In het onderhavige onderzoek is geen aandacht besteed aan de relevantie per criterium. Het verdient dan ook aanbeveling om de meting van de kwaliteit van de verslaggeving verder te verdiepen door aan de gebruikte criteria een wegingsfactor toe te kennen. Bij de toepassing van een dergelijke benchmark komt het ontbreken van concrete informatie over de feitelijke uitstoot van broeikasgassen en de toekomstverwachting ter zake beter tot uitdrukking in de eindscore.

T. Krukkert MSc is als staff audit verbonden aan EY Accountants Nederland.

- Prof. dr. D.A. de Waard RA MA is als hoogleraar Auditing en opleidingsdirecteur van de Executive Master of Accountancy verbonden aan de Rijksuniversiteit Groningen en als buitengewoon hoogleraar aan de University of Curaçao dr. Moises da Costa Gomes.

- De in deze bijdrage uitgewerkte onderzoeksuitkomsten zijn ontleend aan de master's thesis van Thijs Krukkert, begeleid door Dick de Waard.

\section{Noot}

1. De groottecriteria voor organisaties van openbaar belang die moeten voldoen aan Richtlijn 2014/95/EU zijn als volgt: meer dan 500 personeelsleden, omzet groter dan $€ 40$ miljoen en balanstotaal groter dan $€ 20$ miljoen.

\section{Literatuur}

- Adams CA(2004)The ethical, social and environmental reporting-performance portrayal gap. Accounting, Auditing \& Accountability Journal 17(5): 731-757. https://doi.org/10.1108/09513570410567791
- Adams CA, Evans R (2004) Accountability, completeness, credibility and the audit expectations gap. Journal of corporate citizenship 14: 97-115. https://doi.org/10.9774/GLEAF.4700.2004.su.00010 
- Adams CA, Frost GR (2008) Integrating sustainability reporting into management practices. Accounting Forum 32(4): 288-302. https:// doi.org/10.1016/j.accfor.2008.05.002

- Alciatore ML, Callaway Dee C (2006) Environmental disclosures in the oil and gas industry. In: Freedman M, Jaggi B (Eds) Environmental Accounting (Advances in Environmental Accounting \& Management, Vol. 3). Emerald Group Publishing Limited (Bingley): 49-75. https://doi.org/10.1016/S1479-3598(06)03002-0

- Bepari M, Mollik A (2016) Stakeholders' interest in sustainability assurance process: An examination of assurance statements reported by Australian companies. Managerial Auditing Journal 31(6/7): 655-687. https://doi.org/10.1108/MAJ-06-2015-1208

- Berthelot S, Robert A-M (2011) Climate change disclosures: An examination of Canadian oil and gas firms. Issues in Social and Environmental Accounting 5(1/2): 106-123. https://doi.org/10.22164/ isea.v5i2.61

- Brammer S, Pavelin S (2008) Factors influencing the quality of corporate environmental disclosure. Business Strategy and the Environment 17(2): 120-136. https://doi.org/10.1002/bse.506

- Casey RJ, Grenier JH (2014) Understanding and contributing to the enigma of corporate social responsibility (CSR) assurance in the United States. Auditing: A Journal of Practice \& Theory 34(1): 97-130. https://doi.org/10.2308/ajpt-50736

- Chithambo L, Tauringana V (2017) Corporate governance and greenhouse gas disclosure: a mixed-methods approach. Corporate Governance: The International Journal of Business in Society 17(4): 678-699. https://doi.org/10.1108/CG-10-2016-0202

- Cohen JR, Simnett R (2015) A forum on CSR and assurance services. Auditing, A Journal of Practice \& Theory 34(1): vii. https:// doi.org/10.2308/ajpt-10454

- De Beelde I, Tuybens S (2015) Enhancing the credibility of reporting on corporate social responsibility in Europe. Business Strategy and the Environment 24(3): 190-216. https://doi.org/10.1002/bse.1814

- Deegan C, Rankin M, Tobin J (2002) An examination of the corporate social and environmental disclosures of BHP from 1983-1997: A test of legitimacy theory. Accounting, Auditing \& Accountability Journal 15(3): 312-343. https://doi.org/10.1108/09513570210435861

- Dillard J (2011) Double loop learning; or, just another service to sell: A comment on "The case of sustainability assurance: Constructing a new assurance service". Contemporary Accounting Research 28(4): 1267-1277. https://doi.org/10.1111/j.1911-3846.2011.01127.x

- Eisenhardt KM (1989) Agency theory: An assessment and review. Academy of Management Review 14(1): 57-74. https://doi. org/10.2307/258191

- Europese Unie (2014) Directive 2014/95/EU of the European parliament and of the council of 22 October 2014 amending Directive 2013/34/EU as regards disclosure of non-financial and diversity information by certain large undertakings and groups Text with EEA relevance. Official Journal of the European Union. https://eur-lex. europa.eu/legal-content/EN/TXT/?uri=CELEX\%3A32014L0095

- Farooq M, De Villiers C (2019) The shaping of sustainability assurance through the competition between accounting and non-accounting providers. Accounting, Auditing \& Accountability Journal 32(1): 307-336. https://doi.org/10.1108/AAAJ-10-2016-2756

- Fonseca A (2010) How credible are mining corporations' sustainability reports? A critical analysis of external assurance under the requirements of the international council on mining and metals. Corporate Social Responsibility and Environmental Management 17(6): 355-370. https://doi.org/10.1002/csr.230
- Freedman M, Jaggi B (2005) Global warming, commitment to the Kyoto protocol, and accounting disclosures by the largest global public firms from polluting industries. The International Journal of Accounting 40(3): 215-232. https://doi.org/10.1016/j.intacc.2005.06.004

- Freeman RE (1999) Divergent stakeholder theory. Academy of Management Review 24(2): 233-236. https://doi.org/10.5465/ amr.1999.1893932

- Freeman R (2010) Strategic management: A stakeholder approach. Cambridge University Press (Cambridge). https://doi.org/10.1017/ CBO9781139192675

- Gillet C (2012) A study of sustainability verification practices: the French case. Journal of Accounting \& Organizational Change 8(1): 62-84. https://doi.org/10.1108/18325911211205748

- Helfaya A, Whittington M, Alawattage C (2019) Exploring the quality of corporate environmental reporting: Surveying preparers' and users' perceptions. Accounting, Auditing \& Accountability Journal 32(1): 163-193. https://doi.org/10.1108/AAAJ-04-2015-2023

- Henriques I, Sadorsky P (1999) The relationship between environmental commitment and managerial perceptions of stakeholder importance. Academy of Management Journal 42(1): 87-99. https:// doi.org $/ 10.5465 / 256876$

- Hodge K, Subramaniam N, Stewart J (2009) Assurance of sustainability reports: Impact on report users' confidence and perceptions of information credibility. Australian Accounting Review 19(3): 178-194. https://doi.org/10.1111/j.1835-2561.2009.00056.x

- Hummel K, Schlick C, Fifka M (2017) The role of sustainability performance and accounting assurors in sustainability assurance engagements. Journal of Business Ethics 154: 733-754. https://doi. org/10.1007/s10551-016-3410-5

- Jensen MC, Meckling WH (1976) Theory of the firm: Managerial behavior, agency costs and ownership structure. Journal of Financial Economics 3(4): 305-360. https://doi.org/10.1016/0304405X(76)90026-X

- Kuruppu S, Milne MJ (2010) Dolphin deaths, organizational legitimacy and potential employees' reactions to assured environmental disclosures. Accounting Forum 34(1): 1-19. https://doi. org/10.1016/j.accfor.2009.12.001

a Lee TM, Hutchison PD (2005) The decision to disclose environmental information: A research review and agenda. Advances in Accounting 21: 83-111. https://doi.org/10.1016/S0882-6110(05)21004-0

- Liu X, Anbumozhi V (2009) Determinant factors of corporate environmental information disclosure: an empirical study of Chinese listed companies. Journal of Cleaner Production 17(6): 593-600. https://doi.org/10.1016/j.jclepro.2008.10.001

- Martinov-Bennie N, Frost G, Soh DSB (2012) Assurance on sustainability reporting: State of play and future directions. In: Jones $\mathrm{S}$, Ratnatunga J (2012) Contemporary issues in sustainability accounting, assurance and reporting. Emerald Group Publishing Limited (Bingley UK): 267-283.

- O'Dwyer B (2011) The case of sustainability assurance: Constructing a new assurance service. Contemporary Accounting Research 28(4): 1230-1266. https://doi.org/10.1111/j.1911-3846.2011.01108.x

- O’Dwyer B, Owen DL (2005) Assurance statement practice in environmental, social and sustainability reporting: A critical evaluation. The British Accounting Review 37(2): 205-229. https://doi. org/10.1016/j.bar.2005.01.005

- O’Dwyer B, Owen D (2007) Seeking stakeholder-centric sustainability assurance. Journal of Corporate Citizenship 25(1): 77-94. https://doi.org/10.9774/GLEAF.4700.2007.sp.00009 
- Palazzo G, Scherer AG (2006) Corporate legitimacy as deliberation: A communicative framework. Journal of Business Ethics 66(1): 7188. https://doi.org/10.1007/s10551-006-9044-2

- Park J, Brorson T (2005) Experiences of and views on third-party assurance of corporate environmental and sustainability reports. Journal of Cleaner Production 13(10/11): 1095-1106. https://doi. org/10.1016/j.jclepro.2004.12.006

- Perego P, Kolk A (2012) Multinationals' accountability on sustainability: The evolution of third-party assurance of sustainability reports. Journal of Business Ethics 110(2): 173-190. https://doi. org/10.1007/s10551-012-1420-5

- Peters GF, Romi AM (2012) The effect of corporate governance on voluntary risk disclosures: Evidence from greenhouse gas emission reporting. https://pdfs.semanticscholar.org/263c/4327e09d8c66304d880e9446b2576391cb64.pdf

- Pflugrath G, Roebuck P, Simnett R (2011) Impact of assurance and assurer's professional affiliation on financial analysts' assessment of credibility of corporate social responsibility information. Auditing: A Journal of Practice \& Theory 30(3): 239-254. https://doi. org/10.2308/ajpt-10047

- Prado-Lorenzo JM, Rodriguez-Dominguez L, Gallego-Alvarez I, García-Sánchez IM (2009) Factors influencing the disclosure of greenhouse gas emissions in companies worldwide. Management Decision 47(7): 1133-1157. https://doi. org/10.1108/00251740910978340

- Rankin M, Windsor C, Wahyuni D (2011) An investigation of voluntary corporate greenhouse gas emissions reporting in a market governance system: Australian evidence. Accounting, Auditing \& Accountability Journal 24(8): 1037-1070. https://doi. org/10.1108/09513571111184751

- Roberts RW (1992) Determinants of corporate social responsibility disclosure: an application of stakeholder theory. Accounting, Organizations and Society 17(6): 595-612. https://doi.org/10.1016/03613682(92)90015-K

- Rossi A, Tarquinio L (2017) An analysis of sustainability report assurance statements. Managerial Auditing Journal 32(6): 578-602. https://doi.org/10.1108/MAJ-07-2016-1408

- Schoolderman H, Looijenga M, Nandram K (2017) Maak van bestuursverslag geen 'ticking-the-box-exercitie'. Accountant.nl. 19 mei 2017.

- Simnett R, Vanstraelen A, Chua WF (2009) Assurance on sustainability reports: An international comparison. The Accounting Review 84(3): 937-967. https://doi.org/10.2308/accr.2009.84.3.937

- Smith J, Haniffa R, Fairbrass J (2011) A conceptual framework for investigating 'capture'in corporate sustainability reporting assurance. Journal of Business Ethics 99(3): 425-439. https://doi. org/10.1007/s10551-010-0661-4

- Stanny E, Ely K (2008) Corporate environmental disclosures about the effects of climate change. Corporate Social Responsibility and Environmental Management 15(6): 338-348. https://doi. org/10.1002/csr.175

- Suchman MC (1995) Managing legitimacy: Strategic and institutional approaches. Academy of Management Review 20(3): 571610. https://doi.org/10.5465/amr.1995.9508080331

- Ullmann AA (1985) Data in search of a theory: A critical examination of the relationships among social performance, social disclosure, and economic performance of US firms. Academy of Management Review 10(3): 540-557. https://doi.org/10.5465/amr.1985.4278989

- Zadek S, Raynard P, Forstater M, Oelschlaegel J (2004). The future of sustainability assurance. ACCA Research Report No. 86, Certified
Accountants Educational Trust (London). https://www.comunicarseweb.com/sites/default/files/biblioteca/pdf//1301088199_FOSA_Full_Report.pdf

\section{Bijlage 1}

1. Benchmark criteria op basis van Chithambo en Tauringana (2017)

2. Positionering van de onderneming en haar verantwoordelijkheid ten opzichte van klimaatverandering

3. Kansen door klimaatverandering en de ondernemingsstrategieën

4. Identificatie van regelgevingsrisico's als gevolg van klimaatverandering

5. Identificatie van alle andere risico's als gevolg van klimaatverandering

6. Strategische aanpassingen onder invloed van klimaatverandering

7. Kwantitatieve schattingen van regelgevingsrisico's als gevolg van klimaatverandering

8. Kwantitatieve schattingen van alle andere risico's als gevolg van klimaatverandering

9. Impact van klimaatverandering op de bedrijfsvoering, inclusief supply chains

10. Voorgeschreven regelingen waaraan de onderneming moet voldoen

11. Informatie over eventuele opslag van broeikasgassen

12. Corporate governance aspecten inzake klimaatverandering

13. Contactpersoon of verantwoordelijke voor verslaggeving over broeikasgassen

14. Acties/maatregelen die zijn genomen om de gevolgen van klimaatverandering te verminderen/mitigeren

15. Vastgestelde en behaalde broeikasgasemissiedoelstellingen

16. Vergelijkende informatie over gestelde en behaalde doelen

17. Soort ingekochte hernieuwbare energie en de leverancier daarvan

18. Informatie over compensatie van broeikasgasemissies

19. Schatting van toekomstige totale broeikasgasemissies in $\mathrm{CO}_{2}$-tonnen

20. Schatting van toekomstige emissies in scope 1

21. Schatting van toekomstige emissies in scope 2

22. Schatting van toekomstige emissies in scope 3

23. Totale broeikasgasemissies in $\mathrm{CO}_{2}$-metrische tonnen

24. Vergelijkende cijfers over de totale broeikasgasemissies in $\mathrm{CO}_{2}$-metrische tonnen

25. Uitstoot van broeikasgassen per bedrijfseenheid/ type / land

26. Afvoer van broeikasgassen in tonnen $\mathrm{CO}_{2}$

27. Scope 1-emissies

28. Vergelijkende cijfers scope 1-emissies

29. Scope 2-emissies

30. Vergelijkende cijfers scope 2-emissies

31. Scope 3-emissies

32. Vergelijkende cijfers scope 3 -emissies

33. Directe emissies niet opgenomen in de scopes 
34. Emissies niet onder Kyoto-protocol en niet opgenomen in de scopes

35. Emissies door eigen productie van elektriciteit/warmte/stoom verkocht of overgedragen aan een andere organisatie

36. Emissies door inkoop en doorverkoop aan eindgebruikers van eigen productie van elektriciteit/warmte/ stoom

37. Toelichtingen bij afwijkingen in prestaties inzake de totale broeikasgasemissies in $\mathrm{CO}_{2}$-metrische tonnen

38. Toelichtingen bij afwijkingen in de prestaties van scope 1-emissies

39. Toelichtingen bij afwijkingen in de prestaties van scope 2-emissies

40. Toelichtingen bij afwijkingen in de prestaties van scope 3-emissies

41. Reductie in tonnen $\mathrm{CO}_{2}$ per jaar door inkoop hernieuwbare energie

42. Reductie in tonnen $\mathrm{CO}_{2}$ per jaar door inkoop hernieuwbare energie in procenten

43. Prestatiemeting van broeikasgasemissies ten opzichte van interne en externe benchmarks, inclusief ratio's

44. Gebruikte omrekeningsfactoren en methodologie om emissies te meten of te berekenen

45. Uitleg over eventuele wijzigingen ten opzichte van eerder gebruikte methodologie of conversiefactoren

46. Toelichting bij de kwaliteit van de emissiebepaling (zoals oorzaken en omvang van onzekerheden in schattingen)

47. Uitsluitingen van emissies in scope 1

48. Toelichting bij de uitsluiting van emissies in scope 1

49. Uitsluitingen van emissies in scope 2

50. Toelichting bij de uitsluiting van emissies in scope 2

51. Periode waarop het verslag betrekking heeft

52. Gebruikte verslaggevingsrichtlijnen
53. Assurance rapport bij de gepubliceerde informatie

54. Toelichting organisatie onderdelen in het verslag en de consolidatie methodiek

55. Basisjaar

56. Toelichting bij een wijziging van het basisjaar

57. Broeikasgassen waarover is gerapporteerd, inclusief die niet onder het Kyoto-protocol vallen

58. Bronnen van broeikasgassen waarmee wel/geen rekening is gehouden

59. Een lijst van voorzieningen die zijn opgenomen in de bepaling van de broeikasgasemissies

60. Toelichting bij uitsluiting van landen, indien internationaal op totaal niveau wordt gerapporteerd

61. Juridische ondernemingsvorm

\section{Toegevoegde criteria}

a. Handel in broeikasgasemissies wordt buiten de berekening van scope 1 gelaten

b. Broeikasgas emissies door verbranding of biologische afbraak van biomassa worden afzonderlijk van scope 1 gerapporteerd

c. Handel in broeikasgasemissies wordt buiten de berekening van scope 2 gelaten

d. Broeikasgas emissies door verbranding of biologische afbraak van biomassa worden afzonderlijk van scope 3 gerapporteerd

e. Type assurance provider

f. Toegepaste assurance-standaard

g. Herkomst van emissie- en omrekeningsfactoren gebruikt scope 1

h. Herkomst van emissie- en omrekeningsfactoren gebruikt scope 2

i. Herkomst van emissie- en omrekeningsfactoren gebruikt scope 3 